\title{
The show cave of Diros vs. wild caves of Peloponnese, Greece - distribution patterns of Cyanobacteria
}

\author{
Vasiliki Lamprinou $^{1}$, Daniel B. Danielidis ${ }^{1}$, Adriani Pantazidou ${ }^{1}$, Alexandra Oikonomou ${ }^{2}$, \\ and Athena Economou-Amilli ${ }^{1 *}$
}

${ }^{1}$ University of Athens, Faculty of Biology, Department of Ecology and Systematics, Panepistimiopolis, Athens 15784, Greece.
${ }^{2}$ Ministry of Culture and Sports, Ephorate of Palaeoanthropology and Speleology of Southern Greece, 34B Ardittou Str., Athens 11636, Greece.

\begin{abstract}
The karst cave 'Vlychada' of Diros, one of the oldest show caves in Peloponnese, sustains extended phototrophic biofilms on various substrata - on rocks inside the cave including speleothems, and especially near the artificial lighting installation ('Lampenflora'). After a survey of the main abiotic parameters (Photosynthetically Active Radiation -PAR, Temperature $-\mathrm{T}$, Relative Humidity - $\mathrm{RH}$, Carbon Dioxide $-\mathrm{CO}_{2}$ ) three clusters of sampling sites were revealed according to Principal Component Analysis (PCA): i) the water gallery section predominately influenced by $\mathrm{CO}_{2}$, ii) the dry passages influenced by $\mathrm{RH}$ and PAR, and iii) the area by the cave exit at the dry section influenced by temperature. The collected samples from the water gallery section and the dry passages of the cave revealed a total of 43 taxa of Cyanobacteria, with the unicellular/colonial forms being the most abundant. The applied non-metric Multidimensional Scaling Ordination (nMDS) of the cumulative species composition showed a clear distinction between the water gallery section and the dry passages of the cave. Further comparison with previous data from other wild caves of Peloponnese ('Kastria', 'Francthi', and 'Selinitsa') was conducted revealing a distinction between the show cave and the wild ones. Apart from the human impact on cave ecosystems - through aesthetic alteration ('greening') of cave decorations by the 'Lampenflora', and by the cleaning treatments and restoration projects on the speleothems - identification of the organisms constituting the 'Lampenflora' might provide taxonomically and ecologically significant taxa.
\end{abstract}

Keywords: $\quad$ 'Lampenflora', Cyanobacteria, show cave of 'Diros', wild caves, Greece

Received 7 May 2014; Revised 10 July 2014; Accepted 14 July 2014

Citation: $\quad$ Lamprinou V., Danielidis D.B., Pantazidou A., Oikonomou A. and Economou-Amilli A., 2014. The show cave of Diros vs. wild caves of Peloponnese, Greece - distribution patterns of Cyanobacteria. International Journal of Speleology, 43 (3), 335-342, Tampa, FL (USA), ISSN 0392-6672 http://dx.doi.org/10.5038/1827-806X.43.3.10

\section{INTRODUCTION}

The colonization of caves by photosynthetic biota - mainly by microfloristic elements including Cyanobacteria - only takes place where the external diffused sunlight is available such as near cave entrances. There is a delicate balance between the various groups of cave biotic components, particularly among the microfloristic (algae, fungi and bacteria) and microfaunal (small-sized insects, arthropods, bats) cave members (Saiz-Jimenez, 2012). This process is prone to disruption in show cave habitats due to human visitation and modification of the cave environment (Cigna and Burri, 2000; Mulec and Kosi, 2009; Saiz-Jimenez, 2012). The development of caves for mass tourism requires alteration of natural passages, installation of lighting, pathways, platforms, and associated infrastructure (Gillieson,
2011). Under such conditions the oligotrophic nature of cave environments is expected to change through organic inputs that alter both the food web, and the abundance and distribution of cave organisms (Hoyos et al., 1998; Fernández-Cortés et al., 2006; Saiz-Jimenez et al., 2011; Saiz-Jimenez, 2012). Additionally, the artificial lighting system in the show caves affects the photosynthetic microflora in areas around the installed illumination equipment.

The photosynthetic community thriving in proximity to artificial lighting is known as 'Lampenflora'- a term introduced by Dobàt (1963) - and it was first studied in Austrian caves (Kyrle, 1923; Morton and Gams, 1925). Further research has shown that the growth and distribution of these floristic aggregations depend on abiotic factors such as light quality and intensity, temperature, relative humidity, as well as type and coherence of the underlying substratum (Roldán et 
al., 2004; Lamprinou et al., 2012b). Apart from the obvious discoloration of limestone in karst caves, the negative effect of such floristic growths around installed lighting systems includes the gradual alteration of substratum characteristics (Krumbein, 1987; Kováčik, 2000). These alterations are caused by the production of organic acids, which can corrode limestone and negatively affect the aesthetic impact of cave speleothems (Aley, 2004; Smith and Olson, 2007). As a result, modern research has focused on the substratum bio-deterioration by the 'Lampenflora' and on cleaning treatments and restoration projects of hypogean monuments (Caumartin, 1977; Griffin et al., 1991; Iliopoulou-Georgoudaki et al., 1993; Gurnee, 1994; Pantazidou, 1996; Dor and Dor 1999; Grobbelaar, 2000; Byoung-woo, 2002; Olson, 2002; Faimon et al., 2003; Merdenisianos, 2005; Roldán et al., 2006; Albertano et al., 2007; Mulec and Kosi, 2009; Akatova et al., 2009).

Microalgae (cyanobacteria, green algae, diatoms) and bryophytes are considered as the most common floristic components around the artificial lighting systems in show caves, with varying abundance among caves (Grobbelaar, 2000; Aley, 2004). Cyanobacteria represent the dominant phylum colonizing the calcareous surfaces of both wild and show caves, usually thriving as epiliths as well as endoliths; therefore, they have been the focus of extended investigation in various wild caves worldwide (see lit. in Lamprinou et al., 2012b).

The geological substratum of Greece, consisting of limestone in $\sim 2 / 3$ of its landscape, sustains a rich variety of natural karst caves, some of them with interesting microfloristic elements (Pantazidou, 1996; Lamprinou et al., 2009; Lamprinou et al., 2011; Lamprinou et al., 2012 a,b; Lamprinou et al., 2013 a,b). Several Greek karst caves with special geological features have been exploited as tourist attractions, and the expected alteration in the thriving photosynthetic microfloristic elements warrants further investigation. In the present study we selected 'Vlychada'of Diros (Peloponnese, Greece; Fig. 1a) as a prominent example of show caves in order to analyze and correlate species composition of Cyanobacteria with environmental parameters, and for comparison with available data from other wild caves in the wider region of Peloponnese.

\section{MATERIAL AND METHODS}

The cave complex of 'Diros' is composed of one rather wild cave ('Alepotrypa'), and one show cave ('Vlychada' or 'Glyphada') which was selected for further study. The 'Vlychada' show cave $\left(36^{\circ} 38.316^{\prime} \mathrm{N}, 022^{\circ} 22.709^{\prime} \mathrm{E}\right)$ is located on the western shore of Mani Peninsula (Laconia Prefecture) in Peloponnese, Greece (Fig. 1a). The hitherto explored cave length is $14,750 \mathrm{~m}$, with a small part of $2000 \mathrm{~m}$ available for tourist exploitation since 1961 . On the first $1500 \mathrm{~m}$ of the tourist route, starting from the cave entrance, an underground river flows along the cave passage forming a water gallery (i.e. 'karstic cave with hypogean river', Fig. 1b), whereas the remaining $500 \mathrm{~m}$ until the tourist exit are water-free passages (Fig. 1c). Three (3) samplings were conducted during a 3-month survey (December 2012 to March 2013, a time period with rather little tourist traffic of approx. 3000 visitors) at 19 selected sites (see Fig. 1d: entrance, D1; 12 at the water gallery section just above the water level, D2-D13; 5 on the onshore section of the cave, D14-D18; exit, De). Air Temperature $\left(\mathrm{T}{ }^{\circ} \mathrm{C}\right)$, Relative Humidity (RH \%), and Photosynthetically Active Radiation (PAR $\mu \mathrm{mol} \cdot \mathrm{m}^{-2} \cdot \mathrm{s}^{-1}$ ) were measured in situ by a LI-1400 data logger (LI-COR Biosciences, USA) during the survey (Table 1). Four (4) subsamples were collected by scraping off the surface rocks in each sampling site, two of them were incubated in situ in transparent sterile vials and the other two were fixed with formaldehyde solution at a final concentration of $2.5 \%$. Enrichment cultures were obtained in flasks and petri-dishes with BG-11 and BG-11, culture media (Stanier et al., 1971). Cultures were maintained in an incubator (Sanyo, Gallenkamp) under stable conditions $\left({ }^{\circ} \mathrm{C}, 80 \%\right.$, PAR $\left.7 \mu \mathrm{mol} \cdot \mathrm{m}^{-2} \cdot \mathrm{s}^{-1}\right)$ and under daylight at room temperature. For Light Microscopy (LM) fresh and cultured material was observed under a high-resolution light microscope (Axiolab, Zeiss, Germany). Species identification was made according to classical literature (e.g. Anagnostidis and Komárek, 1985, 1988, 1990; Komárek and Anagnostidis, 1986, 1989, 1998, 2005) and certain specific taxonomic papers. Species richness was used as a proxy of cyanobacterial diversity and comparisons were made through ANOVA (Statgraphics Centurion). Species presence/absence data from 13 sites having more than one taxon were analyzed by non-metric Multidimensional Scaling Ordination (nMDS) and Analysis of Similarities (SIMPER) based on Jaccard similarity index, while Principal Component Analysis (PCA) was applied to the measured abiotic parameters (PAR, T, $\mathrm{RH}$ and $\mathrm{CO}_{2}$ ) (PRIMER software v.6.12).

The material collected from the other wild, non-exploited caves of Peloponnese - which were used for comparison (i.e. 'Kastria', 'Francthi' and 'Selinitsa') - was cultured Table 1. Average values and standard deviation of PAR, RH, and T of 'Vlychada' Cave in each sampling site.

\begin{tabular}{|c|c|c|c|}
\hline & PAR & RH & T \\
\hline D1 & $0.297 \pm 0.308$ & $87.75 \pm 5.21$ & $17.03 \pm 0.84$ \\
\hline D2 & $0.595 \pm 0.245$ & $91.05 \pm 5.58$ & $18.35 \pm 1.49$ \\
\hline D3 & $0.063 \pm 0.004$ & $91.46 \pm 5.42$ & $18.84 \pm 1.18$ \\
\hline D4 & $0.137 \pm 0.123$ & $90.36 \pm 3.05$ & $19.53 \pm 0.51$ \\
\hline D5 & $0.155 \pm 0.169$ & $94.63 \pm 2.56$ & $18.67 \pm 0.83$ \\
\hline D6 & $0.027 \pm 0.022$ & $93.72 \pm 6.20$ & $18.56 \pm 1.11$ \\
\hline D7 & $0.113 \pm 0.08$ & $96.33 \pm 2.40$ & $18.02 \pm 0.30$ \\
\hline D8 & $0.101 \pm 0.059$ & $95.48 \pm 2.05$ & $18.25 \pm 0.33$ \\
\hline D9 & $0.865 \pm 0.771$ & $96.43 \pm 1.7$ & $18.00 \pm 0.06$ \\
\hline D10 & $0.537 \pm 0.165$ & $96.60 \pm 1.49$ & $18.07 \pm 0.10$ \\
\hline D11 & $0.511 \pm 0.133$ & $96.30 \pm 1.41$ & $18.17+0.12$ \\
\hline D12 & $0.232 \pm 0.111$ & $93.87 \pm 2.69$ & $18.19 \pm 0.26$ \\
\hline D13 & $0.201 \pm 0.158$ & $96.94 \pm 1.59$ & $18.19 \pm 0.26$ \\
\hline D14 & $0.404 \pm 0.394$ & $97.13 \pm 1.42$ & $18.16 \pm 0.32$ \\
\hline D15 & $0.235 \pm 0.323$ & $96.75 \pm 1.78$ & $18.38 \pm 0.37$ \\
\hline D16 & $1.304 \pm 0.84$ & $96.46 \pm 1.63$ & $18.68 \pm 0.17$ \\
\hline D17 & $0.394 \pm 0.322$ & $94.38 \pm 3.2$ & $19.28 \pm 0.60$ \\
\hline D18 & $1.526 \pm 0.114$ & $96.70 \pm 0.79$ & $19.13 \pm 0.11$ \\
\hline De & $0.156 \pm 0.103$ & $90.45 \pm 1.59$ & $20.05 \pm 0.20$ \\
\hline
\end{tabular}



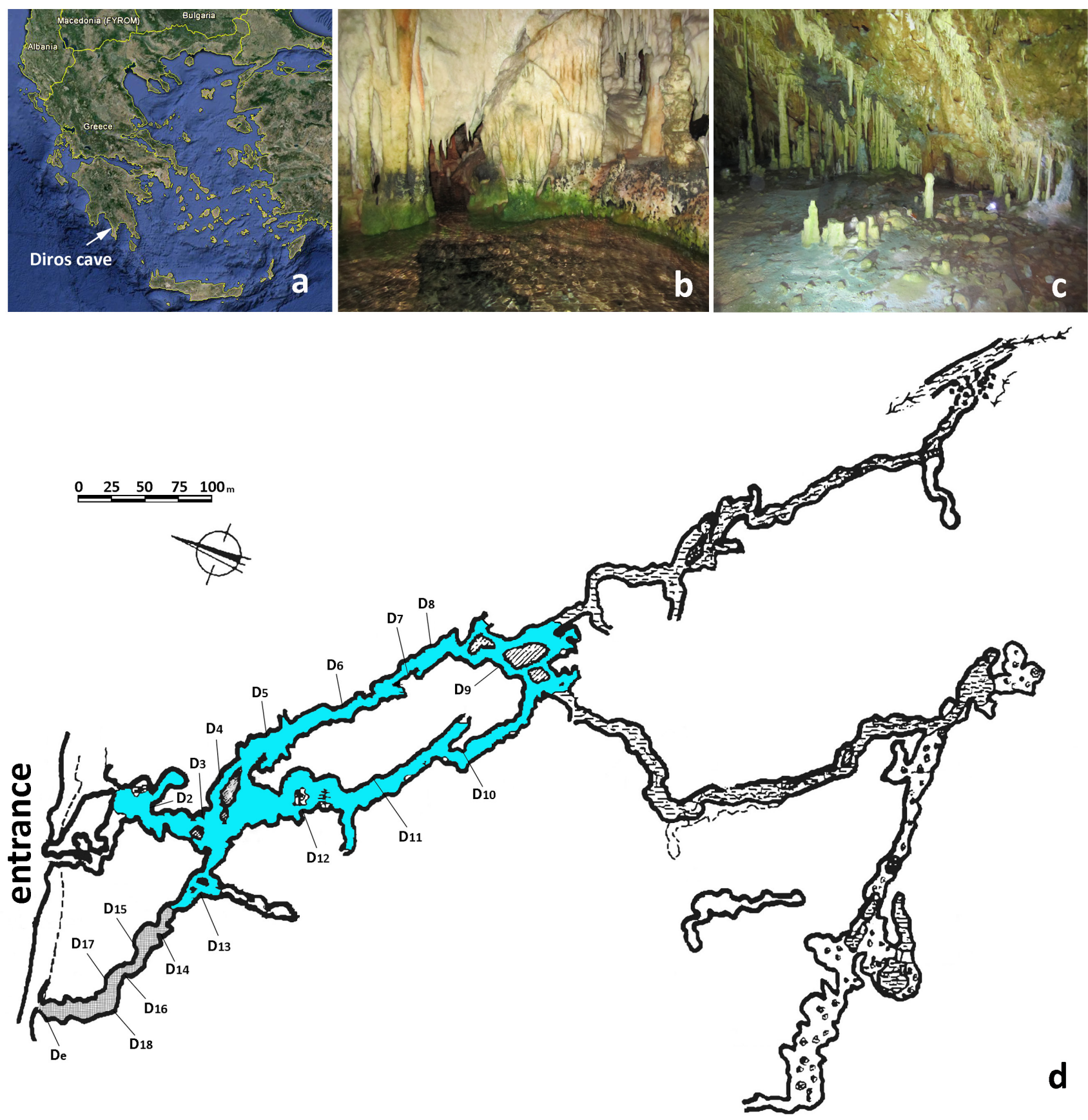

Fig. 1. a) Map of Greece showing the location of Diros Cave; b) A view of the water gallery section of 'Vlychada' Cave; c) Typical view of the dry passages of the cave; d) Map of 'Vlychada' Cave in Diros (from Petrocheilou, 1989-1992) showing the sampling sites (D2-D13, water gallery section; D14-D18, dry passages section; De, exit of the dry passages; D1, entrance is not included).

and statistically analyzed with identical methodology described in detail in Lamprinou et al. (2012b). It is noted that cave 'Kastria' (with 76 taxa of Cyanobacteria) is a wild cave where the sunlight shows a clear gradient from the entrance inwards, and the terrestrial sampling sites were grouped in 3 clusters (the entrance zone, the transition zone, and the dim light zone). Likewise in 'Selinitsa' (with 71 taxa of Cyanobacteria), a cave influenced by the sea, the terrestrial sampling sites were grouped in 3 clusters; whereas in 'Francthi' (with 65 taxa of Cyanobacteria), a cave exposed to open air, the terrestrial sampling sites were grouped in two clusters with seasonal sub-grouping.

\section{RESULTS}

Microscopic analysis (LM) of the samples collected from 'Vlychada' Cave - both fresh and cultured - revealed a total number of 43 taxa of Cyanobacteria, mostly subaerophytic (Table 2) from 19 sampling locations from water gallery section and the dry passages of the cave. In the sampling site by the entrance (D1) only green algae were present. Generally in the remaining sampling sites, the order Chroococcales comprising of unicellular or colonial Cyanobacteria seems to prevail (23 taxa) followed by the filamentous orders Oscillatoriales (17 taxa) and Nostocales ( 3 taxa, 2 of them belonging to the true-branched Cyanobacteria). The dominant Cyanobacteria were represented by 3 taxa, all of them belonging to the order Nostocales, i.e. a true-branched taxon (still under taxonomic investigation) belonging to the family Mastigocladaceae comprising $59.55 \%$ of the species composition in the water gallery section of the cave. Scytonema julianum (42.22\%) and Iphinoe spelaeobios $(24.93 \%)$ were the dominant species for 
Table 2. Taxa of Cyanobacteria identified at each sampling site of 'Vlychada' Cave.

\begin{tabular}{|c|c|c|c|c|c|c|c|c|c|c|c|c|c|c|c|c|c|c|}
\hline & D2 & D3 & D4 & D5 & D6 & D7 & D8 & D9 & D10 & D11 & D12 & D13 & D14 & D15 & D16 & D17 & D18 & $\mathrm{De}$ \\
\hline Aphanocapsa fusco-lutea Hansgirg 1893 & & & & & & & & & & & & & & & & & & + \\
\hline Aphanocapsa muscicola (Meneghini) Wille 1919 & & & & & & & + & & & + & + & & & & & & & + \\
\hline Aphanocapsa parietina Nägeli 1849 & & & & & & & & & & & & & & & & & & + \\
\hline Aphanocapsa rivularis (Carmichael) Rabenhorst 1865 & & & & & & & + & & & & & & & & & & & \\
\hline Aphanocapsa sp. Nägeli 1849 & & & & & & + & & & & & & & & & & & & \\
\hline Aphanothece castagnei (Brébisson) Rabenhorst 1865 & & & + & & & & & + & & & & & + & & + & + & & \\
\hline Aphanothece cf. castagnei (Brébisson) Rabenhorst 1865 & & & & + & + & & & & & & & & & & & & & \\
\hline Aphanothece cf. saxicola Nägeli 1849 & & + & & & & + & + & & & & & & & & & & & \\
\hline Aphanothece microscopica Nägeli 1849 & & & & & & & + & & & & + & & & & & & & + \\
\hline Aphanothece stagnina (Sprengel) A. Braun 1863 & & + & + & & & & & & & & & & & & & & & \\
\hline Chlorogloea novacekii Komárek \& Montejano 1994 & & & & & & & & & & & & & & & & & + & \\
\hline Chroococcus cf. minor (Kützing) Nägeli 1849 & & & & & & + & & & & & + & & & & + & & & \\
\hline Cyanosarcina sp. Kováčik 1988 & & & + & & & + & & & & & & & & & & & & + \\
\hline Eucapsis minor (Skuja) Elenkin 1933 & & & + & & & & & & & & & & & & & & & \\
\hline Gleocapsa cf. atrata Kützing 1843 & & & & & & & + & & & & & & & & & & & \\
\hline Gloeocapsa aeruginosa Kützing 1843 & & & & & & + & + & & & & + & & & & & & & \\
\hline Gloeocapsopsis cyanea (Krieger) Komárek \& Anagnostidis 1994 & & & & & & + & & & & & & & & & & & & \\
\hline Gloeocapsopsis sp. Geitler 1925 & & + & & & & & & & & & & & & & & & & \\
\hline Gloeothece cf. incerta Skuja 1964 & & & & & & & & & & & & & & & + & + & & \\
\hline Gloeothece cf. tepidariorum (A.Braun) Lagerheim 1883 & & & & & & & + & & & & & & & & & & & \\
\hline Gloeothece sp.1 Nägeli 1849 & & + & & & & & & & & & & & & & & & & \\
\hline Gloeothece sp.2 Nägeli 1849 & & & & & & & & & & & & & & & + & & & \\
\hline Iphinoe spelaeobios Lamprinou \& Pantazidou 2011 & + & & + & & & + & + & & & & & & & + & + & + & + & \\
\hline Leptolyngbya boryana (Gomont) Anagnostidis \& Komárek 1988 & & & & & & & & & & & & & & & + & + & & \\
\hline Leptolyngbya cebennensis (Gomont) Umezaki \& Watanabe 1994 & & & & & & & & & & & & & & & & & & + \\
\hline Leptolyngbya cf. laminosa (Gomont) Anagnostidis \& Komárek 1988 & & & + & & & & & & & & & & & & & & & \\
\hline Leptolyngbya ercegovicii (Čado) Anagnostidis \& Komárek 1988 & & & & & & & & & & & & & & & & & + & \\
\hline $\begin{array}{l}\text { Leptolyngbya foveolarum (Rabenhorst ex Gomont) Anagnostidis \& } \\
\text { Komárek } 1988\end{array}$ & & & & & & & & & & & & & & & & & & + \\
\hline $\begin{array}{l}\text { Leptolyngbya gracillima (Zopf ex Hansgirg) Anagnostidis \& Komárek } \\
1988\end{array}$ & & & & & & + & + & & & & & & + & & + & + & & \\
\hline $\begin{array}{l}\text { Leptolyngbya perelegans (Lemmermann) Anagnostidis \& Komárek } \\
1988\end{array}$ & & & + & & & + & + & & & & & & & & & & & + \\
\hline Leptolyngbya sp. Anagnostidis \& Komárek 1988 & & & & & & & & & & & & & & & & & + & \\
\hline Leptolyngbya subtilissima (Kützing ex Hansgirg) Komárek 2001 & & & & & & + & & & & & & & & & & & & \\
\hline Leptolyngbya tenuis (Gomont) Anagnostidis \& Komárek 1988 & & & + & & & & & & & & & & & & & & & + \\
\hline Mastigocladaceae (unidentified filament) & & + & + & + & + & + & + & & + & & + & + & + & + & & & & \\
\hline Phormidium corium Gomont 1892 & & & & & & + & + & & & & & & & & & & & + \\
\hline Phormidium macedonicum Čado 1959 & & + & & & & & & & & & & & & & & & & \\
\hline Phormidium molle Gomont 1892 & & & & & & & & & & & & & & & & & & + \\
\hline Phormidium priestleyi Fritsch 1917 & & + & & & & & + & & & & & & + & & & & & \\
\hline Phormidium tergestinum Kützing ex Anagnostidis \& Komárek 1988 & & & & & & & & & & & & & & & & & & + \\
\hline Pseudanabaena sp. Lauterborn1915 & & & & & & & & & & & & & & & & & & + \\
\hline Scytonema julianum (Kützing) Meneghini 1849 & & & & & & + & & & & & & & + & + & + & + & + & \\
\hline Symploca elegans Kützing 1843 & & & & & & & & & & & & & & & & & & + \\
\hline Synechocystis pevalekii Ercegović 1925 & & & & & & & & & & & & & & & & & & + \\
\hline
\end{tabular}

the water-free section of the cave. It is worth noting that most taxa (22 out of 43) seem to be 'site specific' (i.e. found in one sampling site), with an almost equal representation between the orders Chroococcales (12 taxa) and Oscillatoriales (10 taxa).

The applied nMDS analysis of the cumulative samples per sampling site showed a clear distinction in species composition between the water gallery sites of 'Vlychada' Cave (Dw), the water-free sites (D1), and the exit site (De) (Fig. 2). The PCA showed that the water gallery sampling sites (D5, D6, D7, D8, D12) seem to be associated with elevated $\mathrm{CO}_{2}$ values, while PAR is the prevailing environmental factor affecting species composition in the water-free sampling sites (especially D16, D18) (Fig. 3). Furthermore, the sampling site by the cave exit (De) as well as the water gallery sites (D3, D4) closer to the cave entrance, seem to be predominately influenced by temperature.

Applying the nMDS analysis of the cumulative species composition per sampling site among the other wild caves of Peloponnese (i.e. 'Kastria', 'Francthi' and 'Selinitsa'), a distinction between the 'Vlychada' show cave and the wild ones was prominent (Fig. 4). The average dissimilarity in species composition among the water gallery section of the 'Vlychada' show cave and the wild caves ranged between 90.24 - 93.93\%, while 


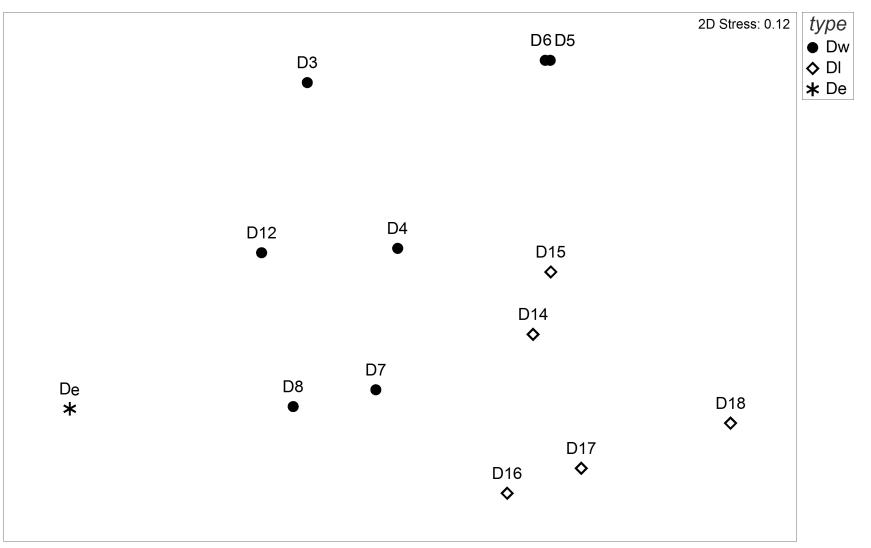

Fig. 2. nMDS analysis of the cumulative samples per sampling sites (DI = sampling sites at the dry passages, $\mathrm{Dw}=$ sampling sites in the water gallery section, $\mathrm{De}=$ sampling site near the tourist exit).

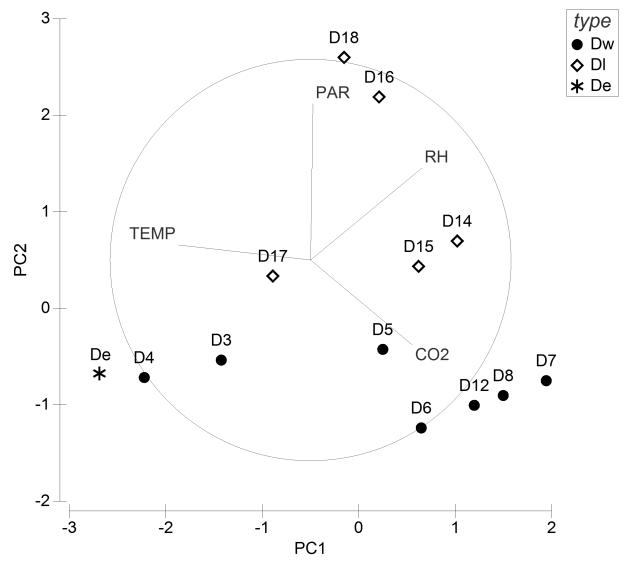

Fig. 3. Principal Component Analysis (PCA) of sampling sites based on environmental parameters. Three clusters are distinguished: i) the water gallery section predominately influenced by $\mathrm{CO}_{2}$, ii) the dry passage section influenced by $\mathrm{RH}$ and PAR and iii) the area by the cave exit at the dry passage section influenced by temperature.

it ranged between 80.61 - 94.65\% among the sites of the dry passages in the show cave compared to the wild ones. Greater similarity was observed between 'Vlychada' Cave and 'Kastria' Cave, particularly expressed in the dry sampling sites of the 'Vlychada' show cave.

\section{DISCUSSION}

Our results on the Cyanobacteria assemblages thriving as epilithic growths on the carbonate substrata in the 'Vlychada' show cave showed a clear distinction between the two well-defined cave habitats, i.e. the dry passages section and water gallery section, suggesting that water availability and other abiotic factors affect species composition.

In the dry passages of 'Vlychada' Cave, cyanobacterial colonies constructed mucilaginous dark-green biofilms typical of terrestrial habitats. Similar mucilaginous biofilms have been observed in various terrestrial low-light environments (Hernández -Mariné et al., 2001; Albertano, 2012).The patchiness of those biofilms can be attributed to differences in the water availability and in the substratum coherence (cf. Hernández-Mariné and Roldán, 2008).

Extended biofilms of heavily calcified filaments dominated by the species Scytonema julianum and

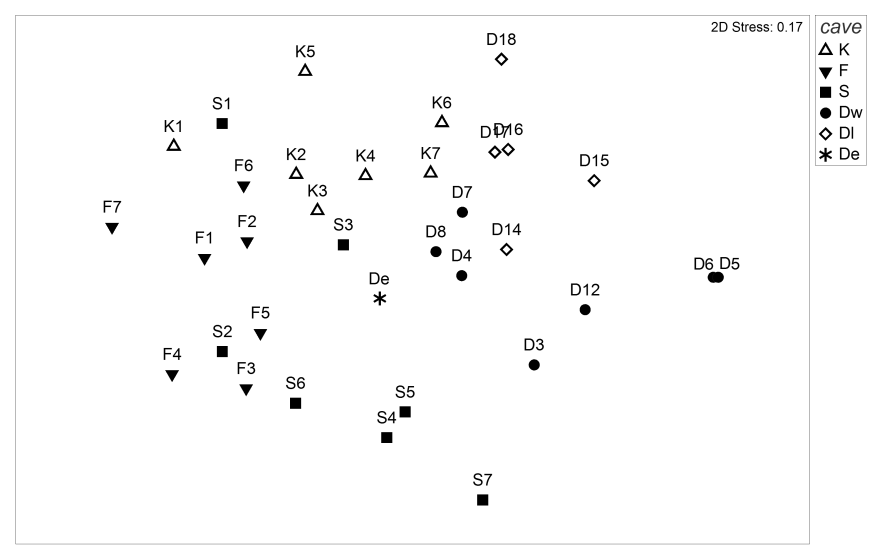

Fig. 4. nMDS analysis of the cumulative samples per sampling site ( $\mathrm{D}$ = 'Vlychada', $\mathrm{K}$ = 'Kastria', $\mathrm{F}$ = 'Francthi', $\mathrm{S}$ = 'Selinitsa') revealing a clear distinction between the show cave and the wild ones.

Iphinoe spelaeobios have been observed in the dry passages of 'Vlychada' Cave. The former species - also present in almost all terrestrial sampling sites of cave 'Kastria' - is well known for the ability to mobilize calcium ions from calcareous substrata (Smith and Olson, 2007; Albertano, 2012), whereas the recent finding of the latter in similar karst habitats of Greek caves (Lamprinou et al., 2012b) suggests a comparable mode of growth. Additionaly, Scytonema julianum is well-adapted to the low irradiance of hypogean sites although it is also tolerant of higher irradiance (Albertano et al., 2000). Therefore, its finding in extended biofilms in the 'Vlychada'show cave and in the wild ones is justified.

As seen by the PCA (Fig. 3), the dry passages of 'Vlychada' Cave is mostly influenced by RH and PAR, particularly in the sampling sites D16 and D18 where an inappropriate system of great light intensity has been installed. In contrast, the accumulation of $\mathrm{CO}_{2}$ seems to be the main abiotic factor influencing species composition in the water gallery section of the cave. The separate position of the sampling site near the cave exit (De) might represent an ecotone since species of neighboring habitats (i.e. epigean and hypogean) coexist increasing the cyanobacterial diversity (15 taxa) thus leading to a clear differentiation from the other sampling sites (cf. Prous et al., 2004).

As seen by the nMDS analysis (Fig. 4), the investigated 'Vlychada' show cave indicates a clear difference from previously studied wild caves in the same region of Peloponnese concerning epilithic assemblages of Cyanobacteria (Lamprinou et al., $2012 \mathrm{~b})$. The lower species number found compared to that of the wild caves might be attributed to the artificial light conditions and its non-continuous operation as a stress factor. In previous studies of show caves, where artificial light influences ambient humidity till the saturation point, Cyanobacteria species number is lower and green algae and mosses dominate (Smith and Olson, 2007; Roldán and Hernández-Mariné, 2009).

As shown from SIMPER analysis among pairs of caves based on the cumulative species composition, smaller dissimilarity is observed between the dry passages section of 'Vlychada' Cave and the wild 'Kastria' Cave, with several species being responsible 
for the distinction. Scytonema julianum and Iphinoe spelaeobios represent the most significant species in the dry passages section of 'Vlychada' Cave (and at the same time those that form the distinction between the dry passages section of this cave and 'Selinitsa' and 'Francthi' Caves). Besides, in the water gallery section of the show cave, a true-branched unidentified taxon belonging to the order Mastigocladaceae was present in all samples constituting the indicative species for the distinction from wild caves.

Show caves have many different sources of disturbances which alter the natural equilibrium of the cave environment. Lighting systems are the most prominent disturbing source with both physical (thermal) and biological effects on the cave environment. The resulting increase of temperature and decrease of $\mathrm{RH}$ lead to the development of aragonite instead of calcite (Forti, 1980). The growth of phototrophs can be notably diminished by the reduction of light intensity (Gurnee, 1994) and by using special lamps that emit light at wavelengths, which do not support maximum absorption of the main photosynthetic pigments (Olson, 2002; Roldán et al., 2006; Mulec and Kosi, 2009).

Another significant source of disturbance is the presence of visitors which causes chemical, biological and thermal pollution. Chemical pollution is mainly due to the emission of carbon dioxide; any increase could affect the chemical equilibrium of the cave formation. The annual heat input $E$ (joules) to a cave is given (Villar et al., 1986) by the formula: $\mathrm{E}=\mathrm{X} \cdot \mathrm{t} \cdot 3600 \cdot \mathrm{N}$ where $X$ is the heat released per person (Joules) ranging from 82-116 J per person when standing still to $\sim 170 \mathrm{~J}$ when walking, $t$ is the visit time, and $N$ is the annual number of visitors. To have an idea of the amount of heat release we calculated it separately for the water gallery section and the dry passages section of 'Vlychada' Cave. Assuming that the annual number of visitors amount from 68,938 to 120,000 (according to the information by the Ephorate of Palaeoanthropology and Speleology of Southern Greece) the average heat release E (J) for the water gallery section of the cave is $1.037 \cdot 10^{10}$ to $1.8 \cdot 10^{10} \mathrm{~J}$, while for the cave water-free part the amount ranges from $1.2 \cdot 10^{11}$ to $7.17 \cdot 10^{11} \mathrm{~J}$. The heat emitted by visitors tends to raise the air temperature in a cave and may modify its humidity (Cigna, 1993; Cigna and Burri 2000; Mulec and Kosi, 2009). As a result, where the number of visitors is large and groups follow each other in close succession, the effects may be cumulative, requiring hours or even days to restore the former equilibrium.

Caves represent laboratories where interdisciplinary scientific research aspects are met improving our knowledge on branches of geomorphology, geology, biology, history, archaeology, and paleontology (Mulec and Kosi, 2009). Therefore, bio-deterioration processes are undesirable in caves of special cultural or natural heritage. Several measures could be taken in order to prevent and control the establishment of the 'Lampenflora' and its side effects, such as: (1) use of 'cool lamps' whose emission spectrum is narrow not supporting photosynthesis (cf. Roldán et al., 2006; Mulec and Kosi, 2009), (2) calculation and control of the visitor capacity (cf. Cigna, 1993; Cigna and Burri, 2000), and (3) control of the already established 'Lampenflora' with physical, chemical or biological methodology (cf. Mulec and Kosi, 2009).

\section{ACKNOWLEDGEMENTS}

This project was financed partly by the Ephorate of Palaeoanthropology and Speleology of Southern Greece, and partly by the National and Kapodistrian University of Athens (Research Project No 70/3/11241).

\section{REFERENCES}

Anagnostidis K. \& Komárek J., 1985 - Modern approach to the classification system of cyanophytes. 1 Introduction. Algological Studies, 38/39: 291-302.

Anagnostidis K. \& Komárek J., 1988 - Modern Approach to the classification system. 3-Oscillatoriales. Algological Studies, 50/53: 327-472.

Anagnostidis K. \& Komárek J., 1990 - Modern approach to the classification system of Cyanophytes.5Stigonematales. Algological Studies, 59: 1-73.

Akatova E., Roldán M., Hernández-Marine M., Gonzalez J.M. \& Saiz- Jimenez C., 2009 - On the efficiency of biocides and cleaning treatments in restoration works of subterranean monuments. In: Science and cultural heritage in the Mediterranean area. Regione Siciliana, Palermo: 316-322.

Albertano P., Bruno L., D’Ottavi D., Moscone D. \& Palleschi G., 2000 - Effect of photosynthesis on $p H$ variation in cyanobacterial biofilms from Roman catacombs. Journal of Applied Phycology, 12: 379-384. http://dx.doi. org/10.1023/A:1008149529914

Albertano P., Bruno L., Piermarini S. \& Bellezza S., 2007 - Monochromatic light and portable spectroradiometry for the conservation of stone monuments affected by phototrophic micro-organisms. In: Drdacky M., Chapuis M. (Eds.) - Safeguarded cultural heritage understanding and viability of the enlarged Europe, vol. 2. Glos Semily, Praha: 814-817.

Albertano P., 2012 - Cyanobacterial biofilms in monuments and Caves. In: Whitton B.A. (Ed.) - Ecology of Cyanobacteria II: Their diversity in space and time. United Kingdom: 317-342.

http://dx.doi.org/10.1007/978-94-007-3855-3_11

Aley T., 2004 - Tourist Caves: Algae and Lampenflora. In: Gunn J. (Ed.) - Encyclopedia of Caves and Karst Science, Taylor and Francis-Routledge. New York: 733-734.

Byoung-woo K., 2002 - Ecological study for the control of green contamination in Korean show caves. In: Proceedings of the 4th Samcheok International Cave Symposium, Samcheok City, South Korea, Kangwon Development Research Institute, 74-76.

Caumartin V., 1977 - Conservation des caverns aménagées. Resultats obtenus dans quelques pays d'Europe occidentale. In: Ford, T.D. (Ed.) - Proceedings of the $7^{\text {th }}$ International Congress of Speleology, Sheffield, U.K., University of Leicester: 96-98.

Cigna A.A., 1993 - Environmental management of tourist caves. Environmental Geology, 21:173-80. http://dx.doi.org/10.1007/BF00775302

Cigna A.A. \& Burri E., 2000 - Development management and economy of show caves. International Journal of Speleology, 29: 1-27. http://dx.doi.org/10.5038/1827-806X.29.1.1

Dobàt K., 1963 - "Höhlenalgen" bedrohen die Eiszeitmalereien von Lascaux. Die Höhle, Wien, 14 (2): 41-45. 
Dor I. \& Dor Y., 1999 - Cyanobacterial flora of the Soreq stalactite cave (Israel) and way of its control. Algological Studies, 94: 115-120.

Faimon J., Štelcl J., Kubešova S. \& Zimák J., 2003 Environmentally acceptable effect of hydrogen peroxide on cave 'lamp-flora', calcite speleothems and limestones. Environmental Pollution, 122: 417-422.

http://dx.doi.org/10.1016/S0269-7491(02)00309-3

Fernández-Cortés A., Calaforra J.M. \& Sánchez-Martos F., 2006 - Spatiotemporal analysis of air conditions as a tool for the environmental management of a show cave (Cueva del Agua, Spain). Atmospheric Environment, 40: 73787394. http://dx.doi.org/10.1016/j.atmosenv.2006.06.045

Forti P., 1980 - Formazione di aragonite nella Grotta di Castellana: un esempio della modificazione indotta dalla turistiazzazione. Grotte d' 1talia, 8: 1-10.

Gillieson D.S., 2011 - Management of caves. In: Van Beyen P. (Ed.) - Karst Management. Springer: 141-158.

Griffin P.S., Indictor N. \& Koestler R.J., 1991 - The biodeterioration of stone: a review of deterioration mechanisms, conservation case histories, and treatment. International Journal of Biodeterioration, 28: 187-207. http://dx.doi.org/10.1016/0265-3036(91)90042-P

Grobbelaar J.U., 2000 - Lithophytic algae: a major threat to the karst formation of show caves. Journal of Applied Phycology, 12: 309-315.

http://dx.doi.org/10.1023/A:1008172227611

Gurnee J., 1994 - Management of some unusual features in the show caves in the United States. International Journal of Speleology, 23: 13-17.

http://dx.doi.org/10.5038/1827-806X.23.1.2

Hernández-Mariné M., Roldán M., Clavero E., Canals A. \& Ariño X., 2001 - Phototrophic biofilm morphology in dim light. The case of the Puigmolto sinkhole. Nova Hedwigia, 123: 237-253.

Hernández-Mariné M. \& Roldán M., 2008 - Characterization of photosynthetic biofilms causing biodeterioration. In: Saiz-Jimenez C. \& Rogerio M.A. (Eds.) - Coalition: 6-12.

Hoyos M., Soler V., Cañaveras J.C., Sánchez-Moral S. \& Sanz-Rubio E., 1998 -Microclimatic characterization of a karstic cave: human impact on micro-environmental parameters of a prehistoric rock art cave (Candamo Cave northern Spain). Environmental Geology, 33: 241-242. http://dx.doi.org/10.1007/s002540050242

Iliopoulou-Georgoudaki J., Pantazidou A. \& Theoulakis P., 1993 - An assessment of cleaning photoautotrophic microflora: the case of 'Perama' cave, Ioannina Greece. Mémoires de Biospéologie, 20: 117-120.

Komárek J. \& Anagnostidis K., 1986 - Modern approach to the classification system of cyanophytes. 2Chroococcales. Algological Studies, 74: 157-226.

Komárek J. \& Anagnostidis K., 1989 - Modern approach to the classification system of Cyanophytes. 4-Nostocales. Algological Studies, 56: 247-345.

Komárek J. \& Anagnostidis K., 1998 - Cyanoprokaryota 1.Teil/ $1^{\text {st }}$ Part: Chroococcales. In: Ettl H., Gärtner G., Heynig H. \& Mollenhauer D. (Eds) - Süsswasserflora von Mitteleuropa 19/1, Gustav Fischer, Jena-StuttgartLübeck-Ulm, 548 p.

Komárek J. \& Anagnostidis K., 2005 - Cyanoprokaryota 2. Teil/ $2^{\text {nd }}$ Part: Oscillatoriales. In: Büdel B., Krienitz L., Gärtner G. \& Schagerl M. (Eds) - Süsswasserflora von Mitteleuropa 19/2, Elsevier/Spektrum, Heidelberg, 759 p.

Kováčik L., 2000 - Cyanobacteria and algae of biodeterioration of stone substrata of historical buildings and other cultural monuments. New Millenium International forum on Conservation of Cultural Property. Daejon, Korea: 44-58.
Krumbein W.E., 1987 - Microbial interaction with mineral materials: Symposium on scientific methodologies applied to works of art. In Houghton D.R., Smith R.N, Eggins O.W. (Eds.) - Biodeterioration 7: Selected Papers Presented at the Seventh International Biodeterioration Symposium, Cambridge, U.K., 6-11 September 1987, New York: Elsevier Applied Science: 78-100.

Kyrle G., 1923 - Grundgriss der theoretischen Speläologie. Wien: Österreichischen Staatsdruckerei, 353 p.

Lamprinou V., Pantazidou A., Papadogiannaki G., Radea C. \& Economou-Amili A., 2009 - Cyanobacteria and associated invertebrates in Leontari cave. Fottea, 9: 155-164.

Lamprinou V., Hernández-Mariné M., Canals T., Kormas K., Economou-Amilli A. \& Pantazidou A., 2011 - Morphology and molecular evaluation of Iphinoe spelaeobiosgen. nov., sp. nov. andLoriellopsiscavernicola gen. nov., sp. nov., two stigonematalean cyanobacteria from Greek and Spanish caves. International Journal of Systematic and Evolutionary Microbiology, 61: 2907291. http://dx.doi.org/10.1099/ijs.0.029223-0

Lamprinou V., Skaraki K., Kotoulas G., EconomouAmilli A. \& Pantazidou A., 2012a - Toxopsis calypsus gen. nov., sp. nov. (Cyanobacteria, Nostocales) from cave 'Francthi', Peloponnese, Greece: a morphological and molecular evaluation. International Journal of Speleology, 63: 2870-2877.

Lamprinou V., Danielidis D., Economou-Amili A. \& Pantazidou A., 2012b - Distribution survey of Cyanobacteria in three Greek caves of Peloponnese. International Journal of Speleology, 41 (2): 267-272. http://dx.doi.org/10.5038/1827-806X.41.2.12

Lamprinou V., Hernández-Mariné M., Pachiadaki M.G., Kormas K.A., Economou-Amilli A. \& Pantazidou A., 2013a - New findings on the true-branched monotypic genus Iphinoe (Cyanobacteria) from geographically isolated caves (Greece). Fottea, 13 (1): 15-23.

Lamprinou V., Skaraki K., Kotoulas G., Anagnostidis K., Economou-Amilli A. \& Pantazidou A., 2013b - A new species of Phormidium (Cyanobacteria, Oscillatoriales) from Greek Caves - morphological and molecular evaluation. Fundamental and Applied Limnology, 182: 109-116. http://dx.doi.org/10.1127/1863-9135/2013/0323

Merdenisianos C., 2005 - The maladie verte (green disease) of the caves. In: Proceedings of the 14th International Congress of Speleology, Athens-Kalamos, Greece, Hellenic Speleological Society: 160-162.

Morton F. \& Gams H., 1925 - Höhlenpflanzen. Verlag Eduard Hölzel, Wien: 227p.

Mulec J. \& Kosi G., 2009 - Lampenflora algae and methods of growth control. Journal of Cave and Karst Studies, 71: 109-115.

Olson R., 2002 - Control of lamp flora in Mammoth Cave National Park. In: Hazslinszky T., (Ed.) - International Conference on Cave Lighting, Budapest, Hungary, Hungarian Speleological Society: 131-136.

Pantazidou A., 1996 - Cyanophytes (Cyanobacteria) in lighted parts of various Greek caves - Problems associated with their growth. Algological Studies, 83: 455-456.

Petrocheilou A., 1989-1992 - La grotte Glyphada Diros, Lakonia. Nouvelles Parties. Bulletin de la Societé Spéléologique de Grèce, 20: 104-109.

Prous X., Ferreira R.L. \& Martins R.P., 2004 - Ecotone delimitation: Epigean-hypogean transition in cave ecosystems. Austral Ecology, 29 (4): 374-382.

http://dx.doi.org/10.1111/j.1442-9993.2004.01373.x

Roldán M., Clavero E., Canals T. A., Gómez-Bolea A., Ariño X., \& Hernández-Mariné M., 2004 - Distribution of phototrophic biofilms in cavities (Garraf, Spain). Nova Hedwigia, 78: 329-351.

http://dx.doi.org/10.1127/0029-5035/2004/0078-0329 
Roldán M., Oliva F., Gónzales del Valle M.A., SaizJimenez C. \& Hernández-Mariné M., 2006 - Does green light influence the fluorescence properties and structure of phototrophic biofilms? Applied and Environmental Microbiology, 72: 3026-3031.

http://dx.doi.org/10.1128/AEM.72.4.3026-3031.2006

Roldán M. \& Hernández-Mariné M., 2009 - Exploring the secrets of the three-dimensional architecture of phototrophic biofilms in caves. International Journal of Speleology, 38 (1): 41-53.

http://dx.doi.org/10.5038/1827-806X.38.1.5

Saiz-Jimenez C., 2012 - Microbiological and environmental issues in show caves. World Journal of Microbiology and Biotechnology, 28: 2453-2464.

http://dx.doi.org/10.1007/s11274-012-1070-x
Saiz-Jimenez C., Cuezva S., Jurado V., FernándezCortés A., Porca E., Benavente D., Cañaveras J.C. \& Sanchez-Moral S., 2011 - Paleolithic Art in Peril: Policy and Science Collide at Altamira Cave. Science, 334: 4243. http://dx.doi.org/10.1126/science.1206788

Smith T. \& Olson R., 2007 - A taxonomic survey of Lamp Flora (Algae and Cyanobacteria) in electrically lit Passages within Mammoth Cave National Park, Kentucky. International Journal of Speleology, 36 (2): 105-114. http://dx.doi.org/10.5038/1827-806X.36.2.6

Stanier R.Y., Kunisawa R., Mandel R. \& Cohen-Bazire G., 1971 - Purification and properties of unicellular blue green algae (Order Chroococcales). Bacteriological Reviews, 35: 171-205.

Villar E., Fernandez P.L., Gutierrez I., Quindos L.S. \& Soto J., 1986 - Influence of visitors on carbon dioxide concentrations in Altamira Cave (Spain). Cave Science, 13 (1): 21-24. 